\title{
Thermovenabulum gondwanense sp. nov., a thermophilic anaerobic Fe(III)-reducing bacterium isolated from microbial mats thriving in a Great Artesian Basin bore runoff channel
}

Correspondence

Bharat Patel

b.patel@griffith.edu.au

\author{
Christopher D. Ogg, Anthony C. Greene and Bharat K. C. Patel
}

Microbial Gene Research and Resources Facility, School of Biomolecular and Physical Sciences, Griffith University, Brisbane, OLD 4111, Australia

\begin{abstract}
A strictly anaerobic, thermophilic bacterium, designated strain $\mathrm{R}^{270^{\top}}$, was isolated from microbial mats thriving in the thermal waters $\left(66^{\circ} \mathrm{C}\right)$ of a Great Artesian Basin bore (registered no. 17263) runoff channel. Cells of strain $\mathrm{R} 270^{\top}$ were straight to slightly curved rods (3.50-6.00×0.75$1.00 \mu \mathrm{m}$ ) that stained Gram-positive, but possessed a Gram-negative cell-wall ultrastructure. Strain R270 ${ }^{\top}$ grew optimally in tryptone-yeast extract-Casamino acids medium at $65{ }^{\circ} \mathrm{C}$ (growth temperature range between 50 and $70{ }^{\circ} \mathrm{C}$ ) and at $\mathrm{pH} 7.0$ (growth $\mathrm{pH}$ range between 6.0 and 9.0). In the presence of 0.02 and $0.10 \%$ yeast extract, pyruvate and Casamino acids were the only substrates fermented from a wide spectrum of substrates tested. Fe(III), Mn(IV), thiosulfate and elemental sulfur were used as electron acceptors in the presence $0.2 \%$ yeast extract, but not sulfate, sulfite, nitrate, nitrite or fumarate. Growth of strain $\mathrm{R} 270^{\top}$ increased in the presence of $\mathrm{Fe}(\mathrm{III})$, which was reduced in the presence of peptone, tryptone, Casamino acids, amyl media, starch, pyruvate, $\mathrm{H}_{2}$ and $\mathrm{CO}_{2}$, but not in the presence of acetate, lactate, propionate, formate, benzoate, glycerol or ethanol. Growth and Fe(III) reduction were inhibited by chloramphenicol, streptomycin, tetracycline, penicillin, ampicillin and $2 \% \mathrm{NaCl}(\mathrm{w} / \mathrm{v})$. The DNA G $+\mathrm{C}$ content of strain R270 ${ }^{\top}$ was $41 \pm 1 \mathrm{~mol} \%\left(T_{\mathrm{m}}\right)$ and phylogenetic analysis of the $16 \mathrm{~S}$ rRNA gene indicated that this isolate was closely related to Thermovenabulum ferriorganovorum DSM $14006^{\top}$ (similarity value of $96.1 \%$ ) within the family 'Thermoanaerobacteraceae', class 'Clostridia', phylum 'Firmicutes'. On the basis of the phylogenetic distance separating the two, together with differences in a number of key phenotypic characteristics, strain $\mathrm{R}^{2} 70^{\top}$ represents a novel species of the genus Thermovenabulum, for which the name Thermovenabulum gondwanense sp. nov. is proposed; the type strain is $\mathrm{R}^{270^{\top}}\left(=\mathrm{KCTC} 5616^{\mathrm{T}}=\mathrm{DSM} 21133^{\mathrm{T}}\right)$.
\end{abstract}

The Great Artesian Basin (GAB) is the world's largest geothermal subsurface aquifer underlying semi-arid regions comprising more than one-fifth of the Australian continent (Habermehl, 1980). Over 5000 bores have been sunk into the GAB to provide a vital water resource to outback Australian communities. During recent years, there has been a significant drop in the GAB groundwater pressure and volume, largely due to water leakage from corroding bores, and this is a matter of great concern. Our recent isolation of several novel metal-reducing microorganisms from the GAB (Kanso et al., 2002; Ogg \& Patel, $2009 \mathrm{a}, \mathrm{b}, \mathrm{c})$ suggests that they could be colonizing the metal casing of bores, thereby contributing to bore

Abbreviation: GAB, Great Artesian Basin.

The GenBank/EMBL/DDBJ accession number for the 16S rRNA gene sequence of strain R270 $\left(=\right.$ KCTC $\left.5616^{\top}=\mathrm{DSM} 21133^{\top}\right)$ is EU443729. corrosion and subsequent complete bore failure. It is widely accepted that metal-reducing micro-organisms have a large impact on the geochemistry of subsurface environments through the cycling of metals and organic matter, and thereby affect water quality and taste (Lovley, 1997). Furthermore, metal-reducing micro-organisms have potential applications in bioremediation, mineral leaching and energy generation processes and are of evolutionary interest as metal reduction is considered to be a very ancient form of respiration (Vargas et al., 1998). In this report, we extend our studies of the GAB environment and describe a strictly anaerobic, thermophilic, metal-reducer, designated strain $\mathrm{R} 270^{\mathrm{T}}$, which represents a novel species of the genus Thermovenabulum.

The red microbial mat used in this study was collected from the runoff channel of the New Lorne Bore (registered bore no. 17263) situated near Blackall, some $1000 \mathrm{~km}$ north-west of Brisbane, Queensland State, Australia (24 
$\left.54^{\prime} 48^{\prime \prime} \mathrm{S} 145^{\circ} 08^{\prime} 18^{\prime \prime} \mathrm{E}\right)$. The bore site and its microbiology have been described previously (Spanevello, 2001; Spanevello et al., 2002; Spanevello \& Patel, 2004). The bore was initially drilled in 1966 and has a depth of $1613 \mathrm{~m}$. The red microbial mats, which thrive at $66^{\circ} \mathrm{C}$, were collected in sterile glass vessels; the vessels were filled to the brim with water from the runoff channel, capped, transported to the laboratory and stored at $4{ }^{\circ} \mathrm{C}$ until used. At the time of sampling, the bore water temperature at the source was $88^{\circ} \mathrm{C}$, the flow rate was $7.6 \mathrm{l} \mathrm{s}^{-1}$, the $\mathrm{pH}$ was 8.5 and iron and manganese concentrations were $0.01 \mathrm{mg} \mathrm{l}^{-1}$. The temperature and $\mathrm{pH}$ of the bore and the runoff channel have not changed over the 8 -year period of our studies.

Enrichment and isolation were performed in anaerobic Patel Laboratory (PL) medium. PL medium was prepared as described previously (Ogg \& Patel, 2009a) and contains $\left(\mathrm{l}^{-1}\right.$ deionized water): $1 \mathrm{~g} \mathrm{NH}_{4} \mathrm{Cl}, 0.6 \mathrm{~g} \mathrm{~K}_{2} \mathrm{HPO}_{4}, 0.3 \mathrm{~g}$ $\mathrm{KH}_{2} \mathrm{PO}_{4}, 0.1 \mathrm{~g} \mathrm{MgCl}_{2} .6 \mathrm{H}_{2} \mathrm{O}, 0.1 \mathrm{~g} \mathrm{CaCl}_{2} .2 \mathrm{H}_{2} \mathrm{O}, 1.0 \mathrm{~g}$ $\mathrm{NaCl}, 12.0 \mathrm{~g}$ HEPES, $1 \mathrm{ml}$ vitamin solution (Wolin et al., 1963), $1 \mathrm{ml}$ trace element solution (Zeikus et al., 1979), $1 \mathrm{ml} 0.2 \%$ resazurin, $2.0 \mathrm{~g}$ yeast extract and $2.0 \mathrm{~g}$ ammonium $\mathrm{Fe}(\mathrm{III})$ citrate (brown). Enrichment cultures were initiated by injecting $500 \mu \mathrm{l}$ red mat suspension (prepared by gentle inversion) into $9.5 \mathrm{ml}$ PL medium. An enrichment culture that transformed the reddishbrown colour of the $\mathrm{Fe}(\mathrm{III})$ to a dark precipitate [Fe(II)] and subsequently resulted in clearing of the medium after 3 days incubation at $70{ }^{\circ} \mathrm{C}$ was regarded as positive for $\mathrm{Fe}(\mathrm{III})$ reduction. $\mathrm{Fe}(\mathrm{III})$ reduction was then confirmed by determining $\mathrm{Fe}(\mathrm{II})$ accumulation using the ferrozine method (Sørensen, 1982). For this, $0.1 \mathrm{ml}$ cell-free culture supernatant was mixed with $3 \mathrm{ml}$ ferrozine reagent and absorbance at $562 \mathrm{~nm}$ was determined after $1 \mathrm{~min}$. The enrichment culture was then serially diluted, incubated under the same conditions and the tube containing the lowest serial dilution $\left(10^{-3}\right)$ was selected. The procedure was repeated at least three times before strain $\mathrm{R} 270^{\mathrm{T}}$ was isolated and selected for further studies. Culture purity was subsequently confirmed by microscopy and 16S rRNA gene sequencing. A pure culture was preserved in a glycerol/PL medium (50:50) mixture at $-20{ }^{\circ} \mathrm{C}$.

Cell morphology was determined by phase-contrast microscopy and by electron microscopy (Kanso \& Patel, 2003). Cells of strain $R 270^{\mathrm{T}}$ were straight to slightly curved rods $(3.50-6.00 \times 0.75-1.00 \mu \mathrm{m})$ that existed singly and in pairs and were peritrichously flagellated. Spores were not observed from cultures that had been grown under suboptimal conditions ( $\mathrm{pH}$ and temperature) or in the presence of $0.2 \%$ glucose or $0.2 \%$ xylose. In addition, cells of strain $\mathrm{R} 270^{\mathrm{T}}$ heated at $95{ }^{\circ} \mathrm{C}$ for $10 \mathrm{~min}$ failed to subculture in PL medium suggesting the absence of heatresistant bodies such as spores. Cells of strain R270 stained Gram-positive, although electron micrographs of thin sections revealed a tri-layered cell wall suggestive of a Gram-negative nature (Fig. 1).

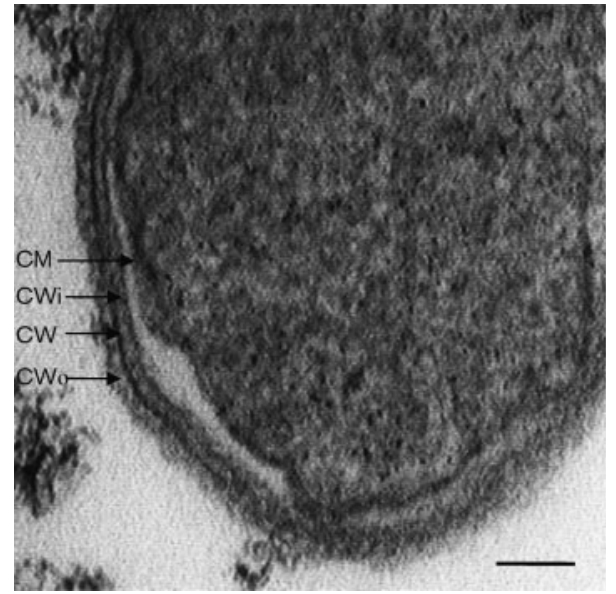

Fig. 1. Transmission electron micrograph of a thin section of strain $\mathrm{R} 270^{\top}$ showing the presence of a cytoplasmic membrane (CM) and a tri-layered cell wall comprising electron-light inner (CWi) and outer (CWo) layers, and an electron-dense middle layer (CW) which is sandwiched between them. Bar, $50 \mathrm{~nm}$.

All growth experiments and nutritional characterization tests were conducted at least twice and cultures were subcultured at least once in the same medium prior to carrying out experiments. Growth studies of strain R270 ${ }^{\mathrm{T}}$ were performed in an anaerobic modified low-phosphatebuffered salts (LPBS) medium (Patel et al., 1985a, b) amended with $0.2 \%$ each of tryptone, yeast extract and Casamino acids (designated TYECas). LPBS contained $\left(1^{-1}\right.$ deionized water): $0.2 \mathrm{~g} \mathrm{MgCl}_{2} \cdot 6 \mathrm{H}_{2} \mathrm{O}, 0.9 \mathrm{~g} \mathrm{NH}_{4} \mathrm{Cl}, 0.75 \mathrm{~g}$ $\mathrm{KH}_{2} \mathrm{PO}_{4}, 1.5 \mathrm{~g} \mathrm{~K}_{2} \mathrm{HPO}_{4}, 1.0 \mathrm{~g} \mathrm{NaCl}, 5 \mu \mathrm{l} 10 \% \mathrm{FeSO}_{4}, 9 \mathrm{ml}$ trace element solution (Zeikus et al., 1979), $5 \mathrm{ml}$ vitamin solution (Wolin et al., 1963), $1 \mathrm{ml} 0.2 \%$ resazurin and $2 \mathrm{ml} 10 \% \mathrm{Na}_{2} \mathrm{~S} .9 \mathrm{H}_{2} \mathrm{O}$. Growth of strain $\mathrm{R}_{2} 70^{\mathrm{T}}$ was tested in TYECas medium at $26-80{ }^{\circ} \mathrm{C}$ and $\mathrm{pH} 4.5-10.0$. Growth was measured spectrophotometrically at $580 \mathrm{~nm}$ by inserting Hungate culture tubes directly into a modified cuvette holder of a Novaspec LKB spectrophotometer (Pharmacia Biotech). Strain R270 ${ }^{\mathrm{T}}$ grew optimally in TYECas medium at $65{ }^{\circ} \mathrm{C}$ (range: $50-70{ }^{\circ} \mathrm{C}$ ) and $\mathrm{pH} 7.0$ (range: $\mathrm{pH}$ 6.0-9.0). However, even under optimal growth conditions, growth was poor (increase in turbidity was 0.14 after $72 \mathrm{~h}$ incubation). Unless indicated otherwise, all subsequent growth experiments were conducted using optimal growth parameters $\left(65^{\circ} \mathrm{C}\right.$ and $\left.\mathrm{pH} 7.0\right)$.

Strain R270 ${ }^{\mathrm{T}}$ was tested for growth in medium D (Brock \& Freeze, 1969) and in aerobic TYECas medium at $65{ }^{\circ} \mathrm{C}$. No visual turbidity was observed for up to 14 days indicating that the isolate could not grow aerobically.

The effect of soluble $\mathrm{Fe}(\mathrm{III})$ on growth of strain $\mathrm{R} 270^{\mathrm{T}}$ was tested in PL medium and the effect of insoluble $\mathrm{Fe}(\mathrm{III})$ was tested in PL medium that lacked ammonium $\mathrm{Fe}$ (III) citrate, but instead contained $0.2 \%$ amorphous $\mathrm{Fe}(\mathrm{III})$ oxyhydroxide [prepared as described by Lovley \& Phillips, 
(1988)]. PL medium that lacked a source of Fe(III) was used as a control. Increase in cell numbers was measured over a 4 day incubation period by the MPN technique (Greenberg et al., 1992) using PL medium. Cell numbers were greatest $\left(2.0 \times 10^{5}\right)$ in medium containing soluble $\mathrm{Fe}(\mathrm{III})$, followed by medium containing insoluble $\mathrm{Fe}(\mathrm{III})$ $\left(1.1 \times 10^{5}\right)$, but an increase in cell numbers was not noted in the $\mathrm{Fe}(\mathrm{III})$-deficient control medium $\left(1.1 \times 10^{2}\right)$.

Substrate utilization tests were performed in sterile LPBS medium amended with 0.02 or $0.1 \%$ yeast extract. Unless otherwise indicated, substrates were added to the medium from sterile, anaerobic stock solutions to a final concentration of 0.2 or $1 \%$. Growth was measured twice daily at $580 \mathrm{~nm}$ until stationary phase was reached or for up to 8 days incubation. Strain $\mathrm{R} 270^{\mathrm{T}}$ grew on $0.2 \%$ pyruvate and Casamino acids, but not on $0.2 \%$ galactose, fructose, sucrose, glucose, maltose, lactose, mannitol, arabinose, xylose, ethanol, glycerol, acetate, lactate or propionate, or on $1 \%$ yeast extract, peptone, tryptone or starch.

The following alternative electron acceptors, namely, fumarate $(20 \mathrm{mM})$, sodium thiosulfate $(20 \mathrm{mM})$, sodium sulfate $(20 \mathrm{mM})$, sodium sulfite $(5 \mathrm{mM})$, elemental sulfur $(1 \%)$, sodium nitrate $(20 \mathrm{mM})$, sodium nitrite $(5 \mathrm{mM})$ and $0.2 \% \mathrm{Mn}(\mathrm{IV})$ [prepared as described by Lovley \& Phillips (1988)], were tested in $\mathrm{Fe}(\mathrm{III})$-deficient PL medium. Utilization of fumarate as an electron acceptor was determined by measuring growth at $580 \mathrm{~nm}$ as described above. Reduction of other alternative electron acceptors was determined as described by Ramamoorthy et al. (2006) and Ogg \& Patel (2009a). Mn(IV) reduction was inferred by a clearing of the media and was further confirmed using the leuco crystal violet manganese oxide detection technique (Spratt et al., 1994). For this, $\mathrm{MnO}_{2}$ concentration was determined by mixing $0.2 \mathrm{ml}$ sample with $4 \mathrm{ml}$ leuco crystal violet reagent, which was diluted, and the absorbance at $562 \mathrm{~nm}$ was determined. Strain R270 ${ }^{\mathrm{T}}$ was able to reduce amorphous $\mathrm{Mn}(\mathrm{IV})$, thiosulfate and elemental sulfur, but not sulfate, sulfite, nitrate, nitrite or fumarate.

The ability of strain $\mathrm{R} 270^{\mathrm{T}}$ to utilize various electron donors in the presence of $\mathrm{Fe}$ (III) was tested in PL medium containing a reduced concentration of yeast extract $(0.02 \%)$. Substrates were added to the medium from sterile, anaerobic stock solutions to a final concentration of $0.2 \%$ and incubations were performed for up to 14 days. Carbohydrates were excluded as test substrates because $\mathrm{Fe}(\mathrm{III})$ reduction can occur spontaneously under sterile conditions (Zavarzina et al., 2002). Fe(III) reduction was determined as described above and was positive for peptone, tryptone, Casamino acids, amyl media (Research Achievement), starch and pyruvate, but not for acetate, lactate, propionate, formate, benzoate, glycerol or ethanol.

The potential for molecular hydrogen to act as an electron donor in the presence or absence of $\mathrm{Fe}$ (III) was tested in PL medium containing a reduced concentration of yeast extract $(0.02 \%)$. PL medium was prepared essentially as described above except after heating for $10 \mathrm{~min}$, the medium was cooled under a stream of $\mathrm{CO}_{2}$ gas and $15 \mathrm{ml}$ was dispensed into $60 \mathrm{ml}$ serum bottles under oxygen-free $\mathrm{H}_{2}: \mathrm{N}_{2}$ (5:95) gas mixture and the medium was autoclaved. Fe(III) reduction and cell numbers were determined as described above. An increase in cell numbers with a concomitant production of $\mathrm{Fe}(\mathrm{II})$ from the reduction of $\mathrm{Fe}(\mathrm{III})$ was observed (Fig. 2). No growth or Fe(III) reduction was observed when $\mathrm{Fe}$ (III) or yeast extract $(0.02 \%)$ was omitted or when $\mathrm{H}_{2}$ was replaced with $\mathrm{N}_{2}$.

Antibiotic sensitivity was determined by adding antibiotics from filter-sterilized stock solutions to PL medium to final concentrations of 10 and $100 \mu \mathrm{g} \mathrm{ml}^{-1}$. Strain $\mathrm{R} 270^{\mathrm{T}}$ was completely inhibited in the presence of ampicillin, penicillin and chloramphenicol (all at $10 \mu \mathrm{g} \mathrm{ml}^{-1}$ ), and streptomycin and tetracycline (both at $100 \mu \mathrm{g} \mathrm{ml}^{-1}$ ). The effect of $\mathrm{NaCl}$ on growth of strain $\mathrm{R} 270^{\mathrm{T}}$ was tested in TYECas and PL medium. For this, $\mathrm{NaCl}$ was weighed directly into the Hungate tube and the medium was dispensed and sterilized. Strain $\mathrm{R} 270^{\mathrm{T}}$ was unable to grow or reduce $\mathrm{Fe}(\mathrm{III})$ at $\mathrm{NaCl}$ concentrations of $2 \%(\mathrm{w} / \mathrm{v})$.

The DNA G $+\mathrm{C}$ content of strain $\mathrm{R} 270^{\mathrm{T}}$ was determined by the thermal denaturation method (Marmur \& Doty, 1962) in a Cintra20 spectrophotometer (GBC Scientific Equipment) with DNA that had been amplified using a TempliPhi Amplification kit (Amersham Biosciences) as described by Ogg \& Patel (2009a). The G + C content of the genomic DNA was calculated to be $41 \pm 1 \mathrm{~mol} \%$.

16S rRNA gene amplification and sequencing were carried out using the method of Ogg \& Patel (2009a). Phylogenetic analysis of the consensus 16S rRNA gene sequence comprising $1423 \mathrm{nt}$ that had been corrected manually for errors indicated that strain $\mathrm{R} 270^{\mathrm{T}}$ was most closely related to the type strain of Thermovenabulum ferriorganovorum (96.1\%), family 'Thermoanaerobacteraceae', class 'Clostridia', phylum 'Firmicutes' (Fig. 3). T. ferriorganovorum was isolated from a Russian hot spring and, like strain $\mathrm{R} 270^{\mathrm{T}}$, is an anaerobic thermophile that grows optimally at nearneutral $\mathrm{pH}$ levels and reduces $\mathrm{Fe}(\mathrm{III}), \mathrm{Mn}(\mathrm{IV})$ and elemental

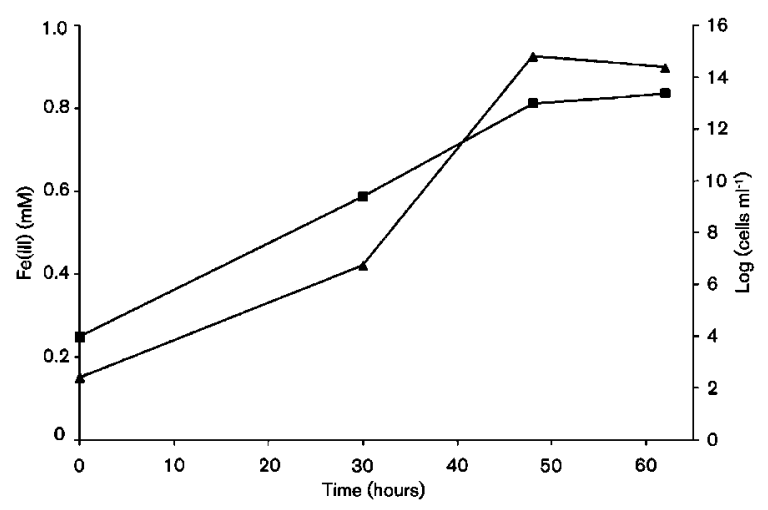

Fig. 2. Growth $(\boldsymbol{\Delta})$ and Fe(II) production ( $\boldsymbol{\square})$ by strain $R 270^{\top}$ in modified PL medium amended with $0.02 \%$ yeast extract instead of $0.2 \%$ and molecular hydrogen $\left[\mathrm{H}_{2}: \mathrm{N}_{2}(5: 95)\right.$ gas mixture $]$ as described in the text. 


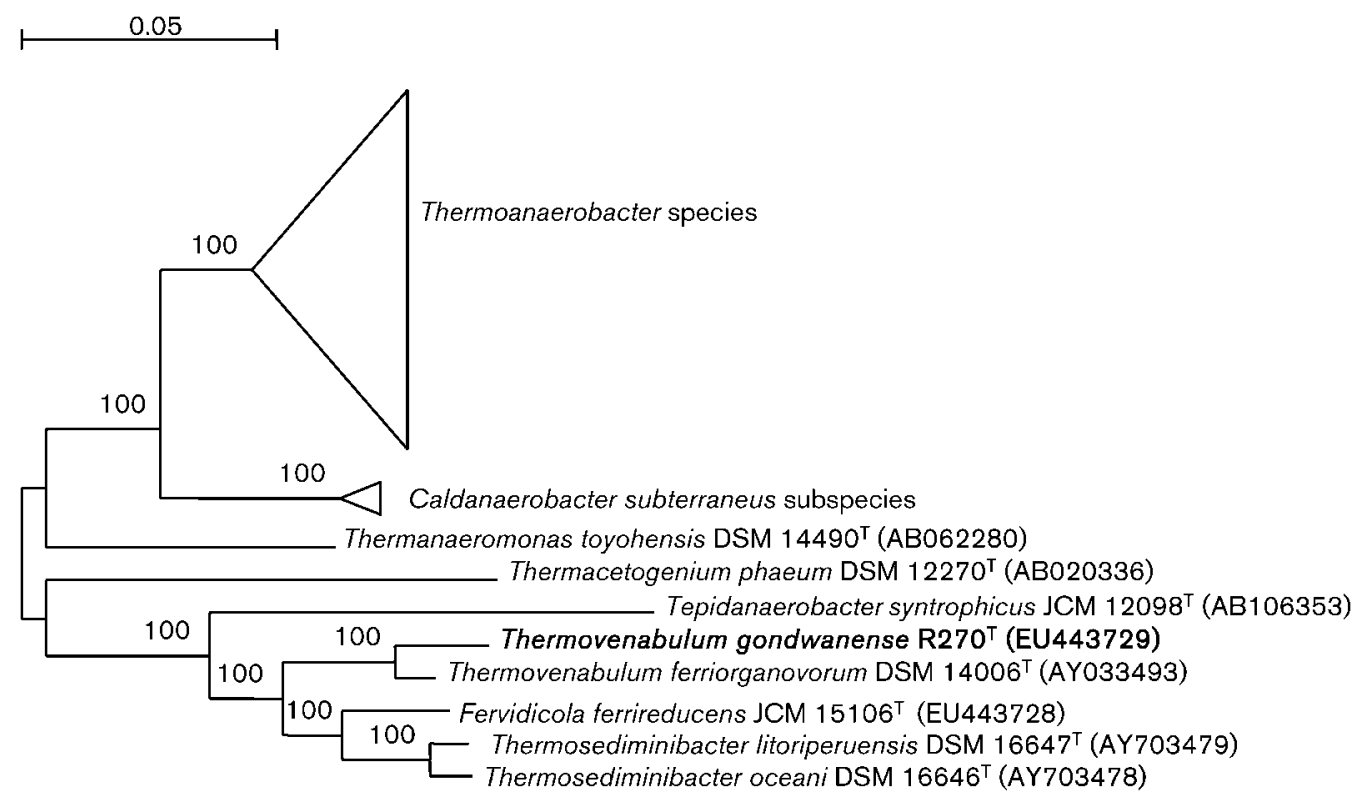

Fig. 3. A dendrogram showing the phylogenetic position of Thermovenabulum gondwanense sp. nov. strain $R 270^{\top}$ and its closest relatives. GenBank accession numbers are given in parentheses. Clusters of members of the same genus or species are indicated by triangles and include: Thermoanaerobacter mathranii DSM $11426^{\top}$ (GenBank accession no. Y11279), Thermoanaerobacter siderophilus DSM 12299 ${ }^{\top}$ (AF120479), Thermoanaerobacter italicus DSM 9252 ${ }^{\top}$ (AJ250846), Thermoanaerobacter acetoethylicus ATCC $33265^{\top}$ (X69336), Thermoanaerobacter wiegelii DSM 10319 ${ }^{\top}$ (X92513),

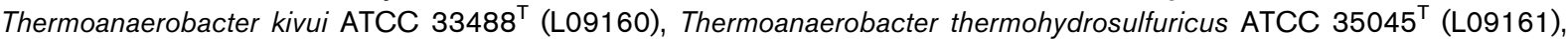
Thermoanaerobacter ethanolicus ATCC $31550^{\top}$ (L09162), Thermoanaerobacter brockii subsp. brockii DSM 1457 ${ }^{\top}$ (L09165), Thermoanaerobacter brockii subsp. finnii DSM $3389^{\top}$ (L09166) and Thermoanaerobacter thermocopriae JCM $7501^{\top}$ (L09167) for the genus Thermoanaerobacter, and Caldanaerobacter subterraneus subsp. tengcongensis $\mathrm{JCM}^{11007^{\top}}$ (AF209708) and Caldanaerobacter subterraneus subsp. yonseiensis DSM $13777^{\top}$ (AF212925) for the species Caldanaerobacter subterraneus. Bootstrap values $>95 \%$ are shown. Bar, 5 nt changes per 100 nt.

sulfur, but not sulfate (Zavarzina et al., 2002). Both strains also grow and reduce $\mathrm{Fe}(\mathrm{III})$ in the presence of molecular hydrogen and yeast extract $(0.02 \%)$, and reduce $\mathrm{Fe}(\mathrm{III})$ in the presence of yeast extract, peptone, Casamino acids, starch and pyruvate, but not acetate, lactate, propionate, formate, ethanol or glycerol. Strain $\mathrm{R} 270^{\mathrm{T}}$ can be differentiated from T. ferriorganovorum by its Gram-negative cellwall ultrastructure, higher DNA $\mathrm{G}+\mathrm{C}$ content, sensitivity to penicillin, higher $\mathrm{pH}$ growth range, lack of heat resistance, inability to form spores and reduce sulfite, nitrate and fumarate, and its restrictive substrate range for growth (e.g. yeast extract, starch, peptone, sucrose, fructose, maltose, ribose and xylose) (Table 1). Based on its close phylogenetic relationship with the genus Thermovenabulum (similarity value of $96.1 \%$ to $T$. ferriorganovorum DSM $14006^{\mathrm{T}}$ ) and its considerable phenotypic differences from T. ferriorganovorum, it is proposed that strain $\mathrm{R} 270^{\mathrm{T}}$ represents a novel species in the genus Thermovenabulum, Thermovenabulum gondwanense sp. nov.

\section{Description of Thermovenabulum gondwanense sp. nov.}

Thermovenabulum gondwanense (gond.wa.nen'se. N.L. neut. adj. gondwanense pertaining to the large land mass known as Gondwana, which included Australia, Africa, India and South America before they separated).

Cells are strictly anaerobic, straight to slightly curved rods. Gram-reaction is positive, but the cell-wall ultrastructure is Gram-negative. Cells possess peritrichous flagella. No spores are detected. Growth occurs between 50 and $70{ }^{\circ} \mathrm{C}$ (optimum temperature $65{ }^{\circ} \mathrm{C}$ ), and between pH 6.0 and 9.0 (optimum pH 7.0). Ferments pyruvate and Casamino acids, but not yeast extract, peptone, tryptone, starch, galactose, fructose, sucrose, glucose, maltose, lactose, mannitol, arabinose, xylose, ethanol, glycerol, acetate, lactate or propionate. $\mathrm{Fe}(\mathrm{III}), \mathrm{Mn}(\mathrm{IV})$, thiosulfate and elemental sulfur are used as electron acceptors, but not sulfate, sulfite, nitrate, nitrite or fumarate. Growth is increased in the presence of $\mathrm{Fe}(\mathrm{III})$, which is reduced in the presence of yeast extract, peptone, tryptone, starch, pyruvate, Casamino acids, amyl media, $\mathrm{H}_{2}$ and $\mathrm{CO}_{2}$, but not acetate, lactate, propionate, formate, benzoate, glycerol or ethanol. Sensitive to streptomycin, tetracycline, penicillin, ampicillin, chloramphenicol and $\mathrm{NaCl}$ concentrations of $2 \%$ and above. 
Table 1. Differential characteristics of strain $R 270^{\top}$ and its closest relative, Thermovenabulum ferriorganovorum DSM $14006^{\top}$

Strains: 1, R270 ${ }^{\mathrm{T}} ; 2$, T. ferriorganovorum DSM $14006^{\mathrm{T}}$ (Zavarzina et al., 2002). +, Positive; -, negative.

\begin{tabular}{|c|c|c|}
\hline Characteristic & 1 & 2 \\
\hline Source & $\begin{array}{l}\text { Microbial mats } \\
\text { from a thermal } \\
\text { aquifer bore } \\
\text { runoff channel }\end{array}$ & Hot spring \\
\hline Geographical location & $\begin{array}{l}\text { Great Artesian } \\
\text { Basin, Australia }\end{array}$ & $\begin{array}{c}\text { Uzon caldera, } \\
\text { Kamchatka } \\
\text { peninsula, } \\
\text { Russia }\end{array}$ \\
\hline Cell width $(\mu \mathrm{m})$ & $0.75-1.0$ & $0.5-0.6$ \\
\hline Cell length $(\mu \mathrm{m})$ & $3.5-6.0$ & $1.5-7.0$ \\
\hline Cell-wall ultrastructure & Gram-negative & Gram-positive \\
\hline Spores observed & - & + \\
\hline Heat resistant & $\begin{array}{l}-\left(95{ }^{\circ} \mathrm{C} \text { for }\right. \\
10 \mathrm{~min})\end{array}$ & $\begin{array}{l}+\left(121{ }^{\circ} \mathrm{C} \text { for }\right. \\
90 \mathrm{~min})\end{array}$ \\
\hline $\mathrm{pH}$ growth range & $6.0-9.0$ & $4.8-8.2$ \\
\hline $\begin{array}{l}\text { Salinity range for growth } \\
{[\%(\mathrm{w} / \mathrm{v}) \mathrm{NaCl}]}\end{array}$ & $0-1$ & $0-3.5$ \\
\hline $\begin{array}{l}\text { Growth inhibition by } 100 \mu \mathrm{g} \\
\text { penicillin } \mathrm{ml}^{-1}\end{array}$ & + & - \\
\hline \multicolumn{3}{|l|}{ Substrate utilization: } \\
\hline Yeast extract & - & + \\
\hline Peptone & - & + \\
\hline Starch & - & + \\
\hline Sucrose & - & + \\
\hline Fructose & - & + \\
\hline Maltose & - & + \\
\hline Ribose & - & + \\
\hline Xylose & - & + \\
\hline \multicolumn{3}{|l|}{ Electron acceptors: } \\
\hline Sulfite & - & + \\
\hline Nitrate & - & + \\
\hline Fumarate & - & + \\
\hline $\begin{array}{l}\text { DNA G }+C \text { content }(\mathrm{mol} \% \\
\left.T_{\mathrm{m}} \text { method }\right)\end{array}$ & 41 & 36 \\
\hline $\begin{array}{l}\text { Similarity to } 16 \mathrm{~S} \text { rRNA gene } \\
\text { sequence of strain } \mathrm{R} 270^{\mathrm{T}}(\%)\end{array}$ & 100 & 96.1 \\
\hline
\end{tabular}

The type strain is $\mathrm{R} 270^{\mathrm{T}}\left(=\mathrm{KCTC} 5616^{\mathrm{T}}=\mathrm{DSM} 21133^{\mathrm{T}}\right)$, isolated from a microbial mat sample from the outflow of a Great Artesian bore (the New Lorne Bore) in Queensland, Australia. The genomic DNA G+C content is $41 \pm 1 \mathrm{~mol} \%$. Phylogenetically, related to Thermovenabulum ferriorganovorum DSM $14006^{\mathrm{T}}$ (96.1\% similarity).

\section{Acknowledgements}

We thank Dr Debbie Stenzel for assistance with electron microscopy studies. C.D.O. is a holder of Griffith University's Australian Postgraduate Research Award (APRA).

\section{References}

Brock, T. D. \& Freeze, H. (1969). Thermus aquaticus gen. nov., a nonsporulating extreme thermophile. J Bacteriol 98, 289-297.

Greenberg, A. E., Clesceri, L. S. \& Eaton, A. D. (1992). Estimation of bacterial density. In Standard Methods for the Examination of Water and Waste Water, pp. 49-50. Washington, DC: American Public Health Association.

Habermehl, M. A. (1980). The Great Artesian Basin, Australia. BMR J Aust Geol Geophys 5, 9-38.

Kanso, S. \& Patel, B. K. C. (2003). Microvirga subterranea gen. nov., sp nov., a moderate thermophile from a deep subsurface Australian thermal aquifer. Int J Syst Evol Microbiol 53, 401-406.

Kanso, S., Greene, A. C. \& Patel, B. K. C. (2002). Bacillus subterraneus sp. nov., an iron- and manganese-reducing bacterium from a deep subsurface Australian thermal aquifer. Int J Syst Evol Microbiol 52, 869-874.

Lovley, D. R. (1997). Microbial Fe(III) reduction in subsurface environments. FEMS Microbiol Rev 20, 305-313.

Lovley, D. R. \& Phillips, E. J. P. (1988). Novel mode of microbial energy metabolism: organic carbon oxidation coupled to dissimilatory reduction of iron or manganese. Appl Environ Microbiol 54, 14721480.

Marmur, J. \& Doty, P. (1962). Determination of the base composition of deoxyribonucleic acid from its thermal denaturation temperature. J Mol Biol 5, 109-118.

Ogg, C. D. \& Patel, B. K. C. (2009a). Caloramator australicus sp. nov., a thermophilic, anaerobic bacterium from the Great Artesian Basin of Australia. Int J Syst Evol Microbiol 59, 95-101.

Ogg, C. D. \& Patel, B. K. C. (2009b). Thermotalea metallivorans gen. nov., sp. nov., a thermophilic, anaerobic bacterium from the Great Artesian Basin of Australia aquifer. Int J Syst Evol Microbiol 59, 964971.

Ogg, C. D. \& Patel, B. K. C. (2009c). Fervidicola ferrireducens gen. nov., sp. nov., a thermophilic anaerobic bacterium from geothermal waters of the Great Artesian Basin, Australia. Int J Syst Evol Microbiol 59, 1100-1107.

Patel, B. K. C., Morgan, H. W. \& Daniel, R. M. (1985a). A simple and efficient method for preparing and dispensing anaerobic media. Biotechnol Lett 7, 277-288.

Patel, B. K. C., Morgan, H. W. \& Daniel, R. M. (1985b). Fervidobacterium nodosum gen. nov. and spec. nov., a new chemoorganotrophic, caldoactive, anaerobic bacterium. Arch Microbiol 141, 63-69.

Ramamoorthy, S., Sass, H., Langner, H., Schumann, P., Kroppenstedt, R. M., Spring, S., Overmann, J. \& Rosenzweig, R. F. (2006). Desulfosporosinus lacus sp. nov., a sulfate-reducing bacterium isolated from pristine freshwater lake sediments. Int J Syst Evol Microbiol 56, 2729-2736.

Sørensen, J. (1982). Reduction of ferric iron in anaerobic, marine sediment and interaction with reduction of nitrate and sulfate. Appl Environ Microbiol 43, 319-324.

Spanevello, M. D. (2001). The phylogeny of prokaryotes associated with Australia's Great Artesian Basin. PhD thesis, School of Biomolecular and Physical Science, Griffith University, Brisbane, Australia.

Spanevello, M. D. \& Patel, B. K. C. (2004). The phylogenetic diversity of Thermus and Meiothermus from microbial mats of an Australian subsurface aquifer runoff channel. FEMS Microbiol Ecol 50, 63-73.

Spanevello, M. D., Yamamoto, H. \& Patel, B. K. C. (2002). Thermaerobacter subterraneus sp. nov., a novel aerobic bacterium 
from the Great Artesian Basin of Australia, and emendation of the genus Thermaerobacter. Int J Syst Evol Microbiol 52, 795-800.

Spratt, H. G., Jr, Siekmann, E. C. \& Hodson, R. E. (1994). Microbial manganese oxidation in saltmarsh surface sediments using a leuco crystal violet manganese oxide detection technique. Estuar Coast Shelf Sci 38, 91-112.

Vargas, M., Kashefi, K., Blunt-Harris, E. L. \& Lovley, D. R. (1998). Microbiological evidence for Fe(III) reduction on early Earth. Nature 395, 65-67.
Wolin, E. A., Wolin, M. J. \& Wolfe, R. S. (1963). Formation of methane by bacterial extracts. J Biol Chem 238, 2882-2886.

Zavarzina, D. G., Tourova, T. P., Kuznetsov, B. B., BonchOsmolovskaya, E. A. \& Slobodkin, A. I. (2002). Thermovenabulum ferriorganovorum gen. nov., sp. nov., a novel thermophilic, anaerobic, endospore-forming bacterium. Int J Syst Evol Microbiol 52, 1737-1743.

Zeikus, J. G., Hegge, P. W. \& Anderson, M. A. (1979). Thermoanaerobium brockii gen. nov. and sp. nov., a new chemoorganotrophic, caldoactive, anaerobic bacterium. Arch Microbiol 122, 41-48. 